This report was prepare as an account of work this report we provernment. Neither sponsored by the United States States Atomic Energy the United States not the United States Atomic nor any of Commission, nor any of their employees, noloyees, their contractors, subcontractors, of their emploses, thei contractors, axpress or implied, on assumes any makes any warranty, expility for the accuracy, comm legal liability or responsibilty for tho accuracy, apparatus, pleteness or useftulness of any infurmation, appat its use product or process disclosed, or represents

product or process privately owned vights.

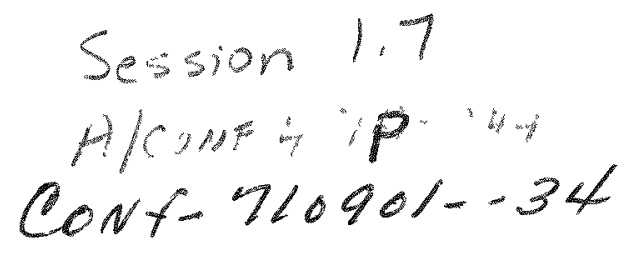

\title{
DEVELOPMENT AND TESTING OF SODIUM COMPONENTS
}

\author{
H. Dieckamp \\ President, Atomics International, Canoga Park, California, U.S.A. \\ B. Wolfe \\ Vice President and Technical Director \\ WADCO Corporation, Richland, Washington, U.S.A. \\ R. W. Dickinson \\ Director, Liquid Metal Engineering Center, Canoga Park, California, U. S. A.
}

\section{INTRODUCTION}

Sodium component experience in the USA has progressed from the development of the small components for EBR-I through plants of substantial thermal capacity. Development of pumps, valves, heat exchangers, steam generators, and fuel handling systems for large economic liquid-metal fast breeder reactors (LMFBR's) will progress from the existing operating experience and technology base, through several stages, to commercial plants.

Performance targets for commercial power-plant components have been identified in the USAEC's 1000-MW(e) plant studies. [1-4] Translation of these targets into specific component designs is the object of a number of contracts to component vendors under the AEC's LMFBR Program. These contracts are pointing toward test evaluation of prototype components in USAEC facilities, principally the Liquid Metal Engineering Center (LMEC). The LMEC provides capability to test prototype sodium pumps, heat exchangers and steam generators, and auxiliary system components in a sodium environment. These prototype components will be further tested and improved in the FFTF and demonstration plant programs of the USA.

\section{SUMMARY OF COMPONENT EXPERIENCE}

Past experience with components for liquid metal systems spans a wide range of operating conditions and sizes. Small components have been operated at temperatures well above the range of interest for economic 


\section{DISCLAIMER}

This report was prepared as an account of work sponsored by an agency of the United States Government. Neither the United States Government nor any agency Thereof, nor any of their employees, makes any warranty, express or implied, or assumes any legal liability or responsibility for the accuracy, completeness, or usefulness of any information, apparatus, product, or process disclosed, or represents that its use would not infringe privately owned rights. Reference herein to any specific commercial product, process, or service by trade name, trademark, manufacturer, or otherwise does not necessarily constitute or imply its endorsement, recommendation, or favoring by the United States Government or any agency thereof. The views and opinions of authors expressed herein do not necessarily state or reflect those of the United States Government or any agency thereof. 


\section{DISCLAIMER}

Portions of this document may be illegible in electronic image products. Images are produced from the best available original document. 
LMFBR's; however, even today's largest components are much smaller than those required for demonstration and commercial plants. The present technology of sodium components is summarized later in this paper, in Tables II to VI.

\section{REQUIREMENTS FOR 1000-MW(e) PLANTS}

The USAEC sponsored a series of design studies of 1000-MW(e) LMFBR's, completed in 1969, to define the performance objectives and development programs for commercial LMFBR's. These studies establish targets for commercial plant components which are summarized in Table I. For almost all parameters, there is a wide span of characteristics, indicating flexibility in design choices and optimization. As detailed designs are completed and component development experience provides further basis for judgment, one can expect variations in optimum plant designs. The major design choices that influence the component requirements are: (1) pot vs loop configuration. (2) outlet temperature, (3) number of heat transfer cir cuits, (4) hot vs cold leg location for the primary pump, (5) under-the-plug vs hot cell refueling, (6) plant control philosophy, with respect to transients imposed, and (7) provisions for decay heat removal.

\section{DEVELOPMENT APPROACH FOR COMPONENTS FOR COMMER CIA L PLANTS}

Commercial plants will require component capabilities in heat transfer and sodium flow volume, up to ten times greater than current experience. To this physical size increase must be added the additional complication of higher sodium temperature $\left(\sim 950^{\circ} \mathrm{F}\right.$ current to $1000-1150^{\circ} \mathrm{F}$ future). These increases in sodium component capabilities place severe requirements on component engineering, with particular emphasis on materials selection and performance.

Comparison of present technology for sodium components with the desired performance of commercial plants shows the importance of further development, to provide manufacturers and utilities with assurance of successful operation of large LMFBR's. One approach is to perform full-scale component testing in synthesized environments, simulating plant operation. This approach could provide the most realistic basis for confidence, but is generally impractical, due to the large capital investment in test facilities and difficulty in predicting and simulating all operating conditions. Further, since life tests would not be practical, because of the long times involved, both accelerated tests and elaborate instrumentation would be required. Accelerated tests require extrapolation, which limits confidence; elaborate instrumentation may well interfere with achieving a prototypical test.

Near the other end of the scale in time and effort are tests in which particularly sensitive portions of components may be tested under simulated conditions, to yield performance data on subcomponents which, when assembled into the whole, could provide reasonable assurance of reliability in the full-sized assembly. This latter course requires a substantial amount of engineering judgment in selecting the critical components, planning and performing tests which are truly representative of conditions in actual service, and interpretation of test data to determine suitability. Subcomponent testing is vulnerable to unanticipated interactions. Particular care is required to assure that subcomponent tests are independent, or that interdependences have been anticipated and taken into account. 
TABLE I

1000-MW(e) PLANT COMPONENT CHARACTERISTICS

\begin{tabular}{|c|c|c|c|c|}
\hline & $A I^{(a)}$ & $\mathrm{B} \& \mathrm{~W}^{(\mathrm{b})}$ & $G E^{(c)}$ & $w^{(d)}$ \\
\hline \multicolumn{5}{|l|}{ Primary Pump } \\
\hline Flow (gal/min) & 62,800 & 37,000 & 63,800 & 150,200 \\
\hline Operating Temperature $\left({ }^{\circ} \mathrm{F}\right)$ & 1,140 & 800 & 809 & 770 \\
\hline Valve & Butterfly & & & None \\
\hline Diameter (in.) & 36 & 26 & & \\
\hline Operating Temperature $\left({ }^{\circ} \mathrm{F}\right)$ & 905 & 1,000 & 809 & \\
\hline \multicolumn{5}{|l|}{ Intermediate Heat Exchanger } \\
\hline Duty $[M W(t h)]$ & 800 & 408 & 808 & 1,300 \\
\hline Surface Area $\left(\mathrm{ft}^{2}\right)$ & 29,900 & 10,500 & 25,800 & 49,800 \\
\hline Maximum Sodium Temperature ( $\left.{ }^{\circ} \mathrm{F}\right)$ & 1,140 & 1,100 & 1,150 & 1,000 \\
\hline Evaporator & $\begin{array}{l}\text { Hockey Stick, } \\
\text { Shell \& Tube }\end{array}$ & $\begin{array}{c}\text { Combined Evaporator- } \\
\text { Superheater, Helical } \\
\text { Coil }\end{array}$ & $\mathrm{U}$ - Tube & J Module, Shell \& Tube \\
\hline Duty $[M W(t h)]$ & 78.5 & 688 & 280 & \\
\hline Surface Area $\left(\mathrm{ft}^{2}\right)$ & 3,640 & 53,820 & 17,880 & \\
\hline Tube Material & $2-1 / 4 \mathrm{Cr}-1 \mathrm{Mo}$ & $2-1 / 4 \mathrm{Cr}-1 \mathrm{Mo}$ & $2-1 / 4 \mathrm{Cr}-1 \mathrm{Mo}$ & Incoloy 800 \\
\hline Maximum Sodium Temperature $\left({ }^{\circ} \mathrm{F}\right)$ & 905 & 1,000 & 942 & \\
\hline Superheater & $\begin{array}{l}\text { Hockey Stick, } \\
\text { Shell \& Tube }\end{array}$ & $\begin{array}{l}\text { Combined Unit (See } \\
\text { evaporator data) }\end{array}$ & U-Tube & I Module, Shell \& Tube \\
\hline Duty $[M W(t h)]$ & 49 & & 118 & \\
\hline Surface Area $\left(\mathrm{ft}^{2}\right)$ & 2,800 & & 8,040 & \\
\hline Tube Material & $\begin{array}{l}\text { Type } 321 \\
\text { Stainless Steel }\end{array}$ & & $\begin{array}{l}\text { Type } 316 \\
\text { Stainless Steel }\end{array}$ & Incoloy 800 \\
\hline Maximum Sodium Temperature $\left({ }^{\circ} \mathrm{F}\right)$ & 1,070 & & 1,071 & 1,040 \\
\hline \multicolumn{5}{|l|}{ Fuel Handling } \\
\hline Type & Under Plug & Under Plug & Hot Cell & Hot Cell \\
\hline Plug Diameter (in.) & 294 & 385 & - & - \\
\hline
\end{tabular}

(a) Atomics International

(b) Babcock \& Wilcox

(c) General Electric

(d) Westinghouse 
Between these two approaches lies a continuous spectrum of compromises, set by technical, financial, and schedule considerations. These may involve the testing of prototype components, though not necessarily full size, with critical areas identified in advance from full-scale designs and past experience. The critical areas are mocked up to simulate the full-scale design, but the whole apparatus need not be in full scale. However, associated with these compromises is a continuous gxadation of confidence level in achieving component performance goals.

It is apparent that there is no one method of development and testing for components which meets the engineering, financial, and schedule requirements simultaneously; there must be a mix, based on engineering and management judgment, which takes into account the conflicting forces entering into a final decision.

The program being undertaken by the United States, to bridge the gap between today's technology and the commercial plants, follows a composite approach, starting with conceptual design of large components based on overall system requirements and past component experience, followed by subcomponent testing to verify selected materials, mechanical, and hydraulic characteristics leading to model and prototype component testing, prior to inclusion in FFTF and the demonstration plant(s). Each demonstration plant will have a supporting test program to prove the particular features of the specific plant design. Operating experience with large components in the demonstration plants and FFTF provide verification of system environmental requirements, validity of prototype extrapolations, maintenance experience, and life information for application to larger commercial plants. The program involves the USAEC, the national laboratories, and the reactor and component manufacturers. The fast reactor progress of other nations also will be considered in the design and testing of U.S. components.

In the remainder of this paper, key technical uncertainties relating to sodium system pumps, valves, heat exchangers, steam generators, and fuel handling equipment will be identified, and the actions required to reduce the uncertainties to acceptable levels will be discussed. The FFTF development and test program will be described, and a summary description of U.S. LMFBR test facilities will be given.

Before reviewing individual component areas, some general discussion of the high-temperature structural design problems is appropriate. It should be kept in mind that these problems are not equally applicable to all LMFBR plant designs. System design and operating conditions can be specified, to mitigate or even eliminate those problem areas which begin to manifest themselves as temperatures approach the creep range (900 to $1000^{\circ} \mathrm{F}$ ), indicating the critical problems will be in the hot leg of the system.

Higher temperature brings the staimless steels commonly used for LMFBR components into the creep range. hermal transients and structural discontinuities may introduce plastic deformation, which interacts with creep effects. This can result in thermal ratchetting and accelerated structural damage, due to interaction of creep and fatigue. Lowering membrane stresses through increasing material thickness does not evade these problems, because the increase in thickness may aggravate the internal strains set up by thermal gradients, to the point where these cyclic stresses can contribute more to material damage than ordinary pressure and bending strains. 
The complex geometries of some components, coupled with the need to account for stress and strain redistribution from plastic deformation and creep, greatly complicates the structural analysis. This has given impetus to a state-of-the-art extension of the application of structural mechanics to three-dimensional creep analyses. A major effort for validation of hightemperature design criteria, based on an elastic-plastic-creep analysis, is required. A companion problem is the definition and analysis of thermal transients.

The current approach in high-temperature structural design provides two paths for the evaluation of structural integrity. One path is derived from conservative adaptations and extensions of previous criteria based on elastic analysis. The other path is based on comprehensive elastic-plastic-creep analyses. Since it will not always be practical and/or economic to design for the simpler, more conservative elastic criteria, developmental testing is required to generate information on the properties of materials in the creep range, and to better understand the relationships between the mechanical properties, failure mechanisms, and behavior of representative components.

Another area of major importance to the development of reliable components for the commercial plants is the establishment of comprehensive quality assurance programs by the component suppliers. The design and testing of prototypes can provide the necessary quality assurance experience, as well as the technology for extrapolation to larger size components. The importance of quality assurance to the success of the commercial plants cannot be overstated.

Sodium pumps

There is good experience with sodium pumps of the general configuration to be used in the commercial plants, but of lower capacity (HNPF, EBR-II, and Fermi). The largest capacity operating units in the U.S. are the Fermi pumps, with a flow rate of $\sim 12,000$ gal/min; thus, the flow scaleup required for the 1000-MW(e) plants ranges from about a factor of $\sim 3$ to a factor of 10. Additional extrapolation in discharge head and operating temperature will be required, as shown in Table II. Similar centrifugal pump designs are used in many LWR plants, providing additional experience in manufacturing and operating large-capacity pumps that approximate the LMFBR size.

Major differences for LMFBR pumps are higher operating temperatures, thermal transients, and longer pump assembly and shaft. The main technical uncertainties in large pumps are: (1) long-term performance and reliability, (2) distortion effects due to temperature and temperature transients, (3) shaft dynamics, (4) alignment control during fabrication, and (5) maintainability.

The on-going AEC LMFBR development and test program, FFTF development, and the demonstration plants will provide the technology and experience needed for commercial plants. LMEC is testing shaft seals and hydrostatic bearings developed by component suppliers in support of the FFTF and the demonstration plants. The next step will be testing of an FFTF prototype pump in the Sodium Pump Test Facility (SPTF) at the LMEC, which will be available to test demonstration plant pumps after completion of the FFTF testing.

Table II shows the anticipated technical evolution of the pumps, from the present technology base to pumps required for commercial LMFBR's. There is a broad range of requirements for commercial LMFBR's, reflecting the 
TABLE II

PUMP EVOLUTION

\begin{tabular}{|c|c|c|c|c|c|c|c|c|c|}
\hline \multirow[b]{3}{*}{ Type } & \multicolumn{6}{|c|}{ Present Technology } & \multirow[b]{2}{*}{ FFTF } & \multirow[b]{2}{*}{$\begin{array}{c}\text { Demonstration } \\
\text { Plants }\end{array}$} & \multirow[b]{2}{*}{$\begin{array}{c}\text { Commercial } \\
\text { Plants }\end{array}$} \\
\hline & SRE-PEP & $\begin{array}{c}\text { SCTI } \\
\text { Primary }\end{array}$ & EBR-II & HNPF & Fermi & LWR's & & & \\
\hline & $\begin{array}{l}\text { Free Surface, } \\
\text { HNPF Type }\end{array}$ & $\begin{array}{l}\text { Free Surface, } \\
\text { HNPF Type }\end{array}$ & $\begin{array}{l}\text { Free Surface, } \\
\text { Sump Type }\end{array}$ & $\begin{array}{l}\text { Free Surface, } \\
\text { HNPF Type }\end{array}$ & $\begin{array}{l}\text { Free Surface, } \\
\text { Fermi Type }\end{array}$ & Centrifugal & Free Surface & Free Surface & Free Surface \\
\hline Flow $(\mathrm{gal} / \mathrm{min})$ & 2700 & 3200 & 5500 & 7200 & 11,800 & $80-100,000$ & 14,500 & $25-60,000$ & $40-150,000$ \\
\hline Head (ft sodium) & 180 & 235 & 200 & 160 & 310 & $250-300$ & 500 & $\sim 400$ & $120-430$ \\
\hline Operating Temperature $\left({ }^{\circ} \mathrm{F}\right)$ & 1000 & 900 & 700 & 945 & 600 & $\sim 650$ & 1050 & $720-1060$ & $770-1140$ \\
\hline Pump Shaft Length (ft) & 12 & 5 & 11 & 16 & 14 & $\sim 15$ & -30 & $\sim 30$ & $\sim 30$ \\
\hline Seal Type & $\begin{array}{l}\text { Face, Onl } \\
\text { Lubricated }\end{array}$ & $\begin{array}{l}\text { Face, Oil } \\
\text { Lubricated }\end{array}$ & $\begin{array}{l}\text { Hermetic } \\
\text { Motor }\end{array}$ & $\begin{array}{l}\text { Face, Oi1 } \\
\text { Lubricated }\end{array}$ & $\begin{array}{l}\text { Face, Oil } \\
\text { Lubricated }\end{array}$ & $\begin{array}{l}\text { Face, Water } \\
\text { Lubricated }\end{array}$ & $\begin{array}{l}\text { Face, Oil } \\
\text { Lubricated }\end{array}$ & $\begin{array}{l}\text { Face, Oil } \\
\text { Lubricated }\end{array}$ & $\begin{array}{l}\text { Face, Oil } \\
\text { \& Gas } \\
\text { Lubricated }\end{array}$ \\
\hline $\begin{array}{l}\text { Hydrostatic Bearing, } \\
\text { Diameter x Length (in.) }\end{array}$ & $10 \times 7$ & $6.5 \times 8.5$ & $12 \times 12$ & $12 \times 12$ & $12 \times 12$ & $24 \times 17$ & $12 \times 12^{(a)}$ & $\sim 24 \mathrm{x} \sim 15$ & $\sim 24 x \sim 15$ \\
\hline Impeller Diameter (in.) & 23 & 16 & 26 & 27 & 37 & $30-45$ & $41^{(a)}$ & $40-70$ & $30-90$ \\
\hline
\end{tabular}

TABLE III

VALVE EVOLUTION

\begin{tabular}{|c|c|c|c|c|c|c|c|c|c|c|c|c|c|c|c|c|c|}
\hline \multirow[b]{3}{*}{ Service } & \multicolumn{8}{|c|}{ Present Technology } & \multirow{2}{*}{\multicolumn{2}{|c|}{ FFTF }} & \multirow{3}{*}{$\frac{\text { SPTE }}{\text { Throttle }}$} & \multirow{2}{*}{\multicolumn{3}{|c|}{ Demonstration Plants }} & \multirow{2}{*}{\multicolumn{3}{|c|}{ Commercial Plants }} \\
\hline & \multirow{2}{*}{$\frac{\text { SRE-PEP }}{\text { Throttle }}$} & \multirow{2}{*}{$\frac{\text { SCTI }}{\text { Throttle }}$} & \multirow{2}{*}{$\frac{\text { EBR-II }}{\text { Throttle }}$} & \multicolumn{3}{|c|}{ HNPF } & \multicolumn{2}{|c|}{ Fermi } & & & & & & & & & \\
\hline & & & & Check & Throttle & Block & Throttle & Check & Block & Check & & Block & Throttle & Check & Block & Throttle & Check \\
\hline Type & $\begin{array}{l}\text { Modified } \\
\text { Plug }\end{array}$ & Butterfly & Angle & $\begin{array}{l}\text { Swing } \\
\text { Disc }\end{array}$ & Ba11 & $\begin{array}{l}\text { Split- } \\
\text { Wedge } \\
\text { Gate }\end{array}$ & Plug & $\begin{array}{l}\text { Swing } \\
\text { Disc }\end{array}$ & $\begin{array}{l}\text { Swing } \\
\text { Gate }\end{array}$ & $\begin{array}{l}\text { Swing } \\
\text { Disc }\end{array}$ & Butterfly & $\begin{array}{l}\text { Split- } \\
\text { Wedge } \\
\text { Gate } \\
\& \text { ? }\end{array}$ & Butterfly & $\Rightarrow$ & $\begin{array}{l}\text { Split- } \\
\text { Wedge } \\
\text { Gate }\end{array}$ & $\begin{array}{l}\text { Butterfly } \\
\& \text { ? }\end{array}$ & ? \\
\hline Diameter (in.) & 8 & 8 & 4 & 16 & 14 & 16 & 6 & 16 & 28 & 16 & 18 & $36-?$ & 36 & 2 & $26-34$ & $22-38$ & 2 \\
\hline $\begin{array}{l}\text { Operating Temperature } \\
\left({ }^{\circ} \mathrm{F}\right)\end{array}$ & 650 & $\begin{array}{l}900 \& x \\
1200\end{array}$ & 700 & 610 & 610 & 945 & 600 & 600 & 1050 & 830 & 1100 & $\begin{array}{r}\sim 700 \\
-1025\end{array}$ & 760 & $\begin{array}{l}720- \\
750\end{array}$ & $\begin{array}{l}670- \\
1000\end{array}$ & $\begin{array}{l}780- \\
1000\end{array}$ & $809-?$ \\
\hline Stem Seal Type & $\begin{array}{l}\text { Torque } \\
\text { Tube }\end{array}$ & Freeze & $\begin{array}{l}\text { Close } \\
\text { Clearance }\end{array}$ & None & Freeze & Freeze & $\begin{array}{l}\text { Double } \\
\text { Bellows }\end{array}$ & None & Freeze & None & Freeze & $\begin{array}{l}\text { Freeze } \\
\& ?\end{array}$ & Freeze & None & $\begin{array}{l}\text { Freeze } \\
\& ?\end{array}$ & $\begin{array}{l}\text { Freeze } \\
\& \text { ? }\end{array}$ & None \\
\hline
\end{tabular}


design approach of each manufacturer. The FFTF and demonstration plants, coupled with on-going development, provide an orderly evolution of pumps from the present state to the large commercial plants. A comparison of detailed parameters, such as bearing loads, specific speed, and linear velocities of the seal, bearing, and impeller, shows that they are within the range of existing sodium pump designs; the major extrapolations required from today's sodium pump designs are the physical size of the components, higher discharge head, and, for hot-leg pumps, higher operating temperature.

The development of manufacturing skill, testing, and operating experience is needed for extrapolation to commercial plant requirements. This experience will be obtained from the prototype pumps to be developed and tested in the SPTF, and the construction and operation of the FFTF and demonstration plant units.

Valves

There is no past experience with sodium valves of the size specified for the 1000-MW(e) plants, although many expected design features have been used previously. The main uncertainties are size scaleup, stem seals, vibration, and thermal transient effects on materials and structures. Valve development and testing is being pursued under the AEC's LMFBR program, to provide information needed to supply the valves for FFTF and SPTF. These valves (see Table III) will provide additional technology needed to permit extrapolation to the demonstration plant valve sizes. Operation of the demonstration plants will provide further information, useful for design of reliable valves for commercial plants.

Intermediate heat exchanger (IHX)

Although no sodium heat exchangers as large as those to be used in the demonstration plants and 1000-MW(e) plants have been built to date, there has been considerable applicable experience with smaller units. Past experience and analysis of LMFBR design work indicate that the principal areas of uncertainty are: (1) shell and tube side flow distributions, (2) tube vibration and wear, (3) maintainability, and (4) thermal transient effects.

A combination of development testing and operating information from the FFTF and demonstration plants is expected to provide sufficient hydraulics design information for the 1000-MW(e) units, as the scaleup from the demonstration plants is not great. Table IV shows the relationship of pres ent technology, demonstration plants, and commercial plants. The Fermi experience to date is up to about one-half rated power.

Maintainability must be carefully considered, because IHX's may become sufficiently radioactive, due to corrosion product deposition, to require semi-remote maintenance. Removable tube bundles permit repairs to be made in a maintenance area. Maintenance on fixed-bundle shell-andtube units will be performed in place. Development of semi-remote techniques potentially will be required for either type, in the event radioactivity levels are too high to permit contact maintenance.

\section{Steam generators}

Of all the sodium system components, the steam generators are generally regarded as the most critical. Some of the past experience has been 
TABLL IV

INTERMEDIATE HEAT EXCHANGER EVOLUTION

\begin{tabular}{|c|c|c|c|c|c|c|c|c|c|}
\hline \multirow[b]{3}{*}{ Type } & \multicolumn{6}{|c|}{ Present Technology } & \multirow{2}{*}{ FFTE } & \multirow{2}{*}{$\begin{array}{c}\text { Demonstra- } \\
\text { tion Plants }\end{array}$} & \multirow{2}{*}{$\begin{array}{l}\text { Commer- } \\
\text { cral Plants }\end{array}$} \\
\hline & SRE & SEFOR & SCTI & EBR-II & INNPI & Fermi & & & \\
\hline & U-Tube & U-Tube & $\begin{array}{l}\text { Shell \& } \\
\text { Tube, } \\
\text { Sine Wave } \\
\text { Tube }\end{array}$ & $\begin{array}{l}\text { Shell \& } \\
\text { Tube, } \\
\text { Removable } \\
\text { Bundle }\end{array}$ & $\begin{array}{l}\text { Shell \& } \\
\text { Tube } \\
\text { Bellows } \\
\text { in Shell }\end{array}$ & $\begin{array}{l}\text { Shell \& } \\
\text { Tube } \\
\text { Floating } \\
\text { Head, } \\
\text { Removable } \\
\text { Bundle }\end{array}$ & $\begin{array}{l}\text { Shell \& } \\
\text { Tube } \\
\text { Removable } \\
\text { Bundle }\end{array}$ & $\begin{array}{l}\text { Shell \& Tube, } \\
\text { Removable } \\
\text { Bundle, \& } \\
\text { Frixed Shell \& } \\
\text { Tube }\end{array}$ & $\begin{array}{l}\text { Shell \& Tube, } \\
\text { Removable } \\
\text { Bundle, \& } \\
\text { Frxed Shell \& } \\
\text { Tube }\end{array}$ \\
\hline $\begin{array}{l}\text { Duty } \\
{[M W(t h)]}\end{array}$ & 20 & 20 & 30 & 63 & 43 & 143 & 133 & $263 \quad 625$ & $400-1300$ \\
\hline $\begin{array}{l}\text { Surface Area } \\
\left(f t^{2}\right)\end{array}$ & I 155 & 483 & 1393 & 4540 & 2875 & 5840 & 8800 & $=-24,000$ & $10,000-50,000$ \\
\hline $\begin{array}{l}\text { Number of } \\
\text { Tubes }\end{array}$ & 316 & 161 & 462 & 3026 & 1395 & 1860 & 1550 & $?-2900$ & $3400-7400$ \\
\hline $\begin{array}{l}\text { Maxamum } \\
\text { Sodium } \\
\text { Temperature } \\
\left({ }^{\circ} \mathrm{F}\right)\end{array}$ & 960 & 809 & 1200 & 883 & 945 & 900 & 1050 & $1000-1060$ & $1000-1150$ \\
\hline $\begin{array}{l}\text { Log Mean } \\
\text { Temperature } \\
\text { Difference } \\
(\text { deg } F)\end{array}$ & 60 & 144 & 62 & 48 & 50 & 80 & 92 & $64-80$ & $65-120$ \\
\hline
\end{tabular}


poor; however, there has been satisfactory experience for the relatively short periods of operation in SRE and HNPF, and, for a longer operating period, in EBR-II. The early problems with the single-wall-tube Fermi units appear to have been corrected. Recent testing of the ALCO unit in the SCTI resulted in severe tube sheet cracking. An investigation of the cause of failure is in progress. The concerns regarding steam generators can be broadly classified into the following categories: (1) structural integrity and reliability, (2) operational stability, (3) hydraulic performance and flow distribution, (4) accommodation of tube leaks and sodium-water reactions, and (5) rapid and reliable leak detection.

The steam generator experience which is applicable to the demonstration plants or the commercial plants is with small units. The key steps in developing steam generators for the commercial plants are the testing of models in the SCTI and the construction and operation of demonstration plant units. This evolution is summarized in Table V. The Fermi experience to date is up to about one-half rated power. It is seen, from this table, that there is still a significant extrapolation in unit size and temperatures from the demonstration plant, for some of the designs of 1000-MW(e) plants. An example of the important role of testing is provided by the Atomics Inter national program, in support of their demonstration plant, wherein a steam generator module has been supplied to the AEC for testing in the SCTI.

Fuel handling

The fuel handling systems being considered by LMFBR manufacturers in the United States are of two basic types: (1) the under-plug system, using rotatable plugs, and (2) the hot-cell type (see Table VI). There are wide variations in the design details of these systems.

There is substantial satisfactory experience with under-plug systems at EBR-II and Fermi; however, the diameters of the rotatable plugs must be increased, by factors of 2 to 3 , for large plants. There is a great deal of experience with both in-vessel and ex-vessel fuel transfer machines, similar to those planned for commercial plants. The experience with the hot cell refueling system at SEFOR also has been quite good, lending confidence to the selection of that type for large systems as well.

Because of the variation of design details between manufacturers, each organization plans development work for their demonstration plant. In general, these programs will involve mockups and proof tests, as well as component-level tests. The FFTF will provide important additional experience relevant to under-plug mechanical equipment, as well as overall system data.

The most important technical uncertainties associated with fuel handling systems are: (1) the effect of irradiation-induced swelling and bowing of core components on fuel handling, (2) sodium frost, (3) possible plutonium contamination from leaking or failed fuel rods, and (4) the capability to accommodate failures in a safe manner. None of these appear to involve questions of basic feasibility. The FFTF and demonstration plants and their associated test programs will provide proven systems for the commercial plants, as there is essentially no scaleup required. 
TABLE V

STEAM GENERATOR EVOLUTION

\begin{tabular}{|c|c|c|c|c|c|c|c|c|}
\hline & \multicolumn{5}{|c|}{ Present Technology } & \multirow{2}{*}{$\begin{array}{l}\text { AI Module } \\
\text { SCTI }\end{array}$} & \multirow{2}{*}{$\begin{array}{c}\text { Demonstration } \\
\text { Plants }\end{array}$} & \multirow{2}{*}{$\begin{array}{c}\text { Commercial } \\
\text { Plants }\end{array}$} \\
\hline & $\mathrm{SRE}$ & $\begin{array}{l}\text { ALCO Unit } \\
\text { SCTI }\end{array}$ & EBR-II & HNPF & Fermi & & & \\
\hline Type & $\begin{array}{l}\text { Combined Superheater- } \\
\text { Evaporator, Once- } \\
\text { Through Duplex U- } \\
\text { Tube, Mercury Third } \\
\text { Fluıd }\end{array}$ & $\begin{array}{l}\text { Once-Through } \\
\text { Shell \& Tube, } \\
\text { Sine Wave }\end{array}$ & $\begin{array}{l}\text { Shell \& Tube, } \\
\text { Duplex Bonded }\end{array}$ & $\begin{array}{l}\text { Bayonet Duplex } \\
\text { Tube, Helium } \\
\text { Third Fludd }\end{array}$ & $\begin{array}{l}\text { Combined } \\
\text { Superheater- } \\
\text { Evaporator, } \\
\text { Once-Through } \\
\text { Serpentine Tube }\end{array}$ & $\begin{array}{l}\text { Hockey Stıck, } \\
\text { Shell \& Tube }\end{array}$ & $\begin{array}{l}\text { Separate Super- } \\
\text { heater, Evaporator, } \\
\text { \& Reheater, Once- } \\
\text { Through \& Rectrcu- } \\
\text { lating Shell \& Tube, } \\
\text { \& Bayonet Tube }\end{array}$ & $\begin{array}{l}\text { Separate Super- } \\
\text { heater, Evapo- } \\
\text { rator, \& Reheater, } \\
\text { \& Combuned Super- } \\
\text { heater, Evapo- } \\
\text { rator, \& Reheater, } \\
\text { Shell \& Tube } \\
\text { Hockey Stick, J } \\
\text { Module, U-Tube, } \\
\text { \& Helical Corl }\end{array}$ \\
\hline \multicolumn{9}{|l|}{ Duty/Module $[M W(t h)]$} \\
\hline & 30 & 30 & 57 & 69 & 143 & 26 & $76-263$ & $80-690$ \\
\hline \multicolumn{9}{|l|}{$\underset{\left(\mathrm{ft}^{2}\right)}{\operatorname{Surface}}$ Area/Module } \\
\hline Evaporator & \multirow{2}{*}{$\begin{array}{l}2790 \text { Soduum Side, } \\
1580 \text { Water Side }\end{array}$} & \multirow{2}{*}{1260} & 620 & 3,680 & \multirow{2}{*}{10,800} & \multirow{2}{*}{1,475} & $4,400-20,000$ & $4,000-54,000$ \\
\hline Superheater & & & 620 & 2,150 & & & $4,400-8,300$ & $2,800-8,000$ \\
\hline \multicolumn{9}{|c|}{ Number of Tubes/Module } \\
\hline Evaporator & \multirow{2}{*}{199} & \multirow{2}{*}{300} & 73 & 679 & \multirow{2}{*}{1,200} & \multirow{2}{*}{158} & $475-1,2,40$ & $340-760$ \\
\hline Superheater & & & 73 & 560 & & & $250-475$ & $380-440$ \\
\hline $\begin{array}{l}\text { Maximum Sodxum } \\
\text { Temperature }\left({ }^{\circ} \mathrm{F}\right)\end{array}$ & 900 & 1175 & 866 & 895 & 820 & 950 & $935-1000$ & $1,040-1,070$ \\
\hline \multicolumn{9}{|l|}{ Steam Conditions } \\
\hline Pressure $\left(1 \mathrm{bf} / \mathrm{mn}^{2}\right)$ & 600 & 2,200 & 1,250 & 850 & 885 & 2,400 & $1,450-2,400$ & 2,500 \\
\hline Temperature $\left({ }^{\circ} \mathrm{F}\right)$ & 825 & 1,050 & 850 & 850 & 780 & 900 & $900-950$ & $950-1,000$ \\
\hline Materials & $\begin{array}{l}\text { Type } 304 \text { Stannless } \\
\text { Steel }\end{array}$ & $\begin{array}{l}\text { Type } 316 \\
\text { Stanless } \\
\text { Steel \& Type } \\
316 \text { - Inconel }\end{array}$ & $2-1 / 4 \mathrm{Cr}-1 \mathrm{Mo}$ & $\begin{array}{l}2-1 / 4 \mathrm{Cr}-1 \mathrm{Mo} \& \\
5 \mathrm{Cr}-1 / 2 \mathrm{Mo}- \\
1 / 2 \mathrm{Tl}\end{array}$ & $2-1 / 4 \mathrm{Cr}-1 \mathrm{Mo}$ & $2-1 / 4 \mathrm{Cr}-1 \mathrm{MO}$ & $2-1 / 4 \mathrm{Cr}-1$ Mo \& ? & $\begin{array}{l}2-1 / 4 \mathrm{Cr}-1 \mathrm{Mo} \\
\text { Stainless Steel } \\
\& \text { Incoloy }\end{array}$ \\
\hline
\end{tabular}


TABLE VI

FUEL HANDLING EVOLUTION

\begin{tabular}{|c|c|c|c|c|c|c|c|c|}
\hline & \multicolumn{5}{|c|}{ Present Technology } & \multirow{2}{*}{ FFTF } & \multirow{2}{*}{$\begin{array}{l}\text { Demonstration } \\
\text { Plants }\end{array}$} & \multirow{2}{*}{$\begin{array}{l}\text { Commerciai } \\
\text { Plants }\end{array}$} \\
\hline & SRE & SEFOR & EBR-II & HNPF & Fexm1 & & & \\
\hline Type & Through Plug & Hot Cell & Under Plug & Through Plug & Under Plug & Under Plug & $\begin{array}{l}\text { Under Plug \& Hot } \\
\text { Cell }\end{array}$ & $\begin{array}{l}\text { Under Plug \& } \\
\text { Hot Cell }\end{array}$ \\
\hline \multicolumn{9}{|l|}{ Dlug } \\
\hline Type & $\begin{array}{l}\text { Rotation for } \\
\text { Maintenance }\end{array}$ & & $\begin{array}{l}\text { Double } \\
\text { Rotatable }\end{array}$ & $\begin{array}{l}\text { Rotation for } \\
\text { Maintenance }\end{array}$ & Single Rotatable & Three Rotatable & Double Rotatable & $\begin{array}{l}\text { Double \& Triple } \\
\text { Rotatable }\end{array}$ \\
\hline Drameter (Large) (in) & 142 & & 142 & 230 & 112 & 75 & & $294-385$ \\
\hline Sea1 & $\begin{array}{l}\text { Frozen } \\
\text { Metal }\end{array}$ & & $\begin{array}{l}\text { Liquid Metal } \\
\text { Trough }\end{array}$ & Frozen Metal & Silicone Rubber & Silicone Rubber & $\begin{array}{l}\text { Silicone Rubber, } \\
\text { Liquid Metal } \\
\text { Trough }\end{array}$ & $\begin{array}{l}\text { Silicone Rubber, } \\
\text { Liquid Metal } \\
\text { Trough }\end{array}$ \\
\hline \multicolumn{9}{|l|}{ In-Vessel Transfer } \\
\hline Function & None & See Below & $\begin{array}{l}\text { Transfer \& } \\
\text { Rotate }\end{array}$ & None & Transfer & $\begin{array}{l}\text { Transfer \& } \\
\text { Rotate }\end{array}$ & $\begin{array}{l}\text { Transfer \& } \\
\text { Rotate }\end{array}$ & $\begin{array}{l}\text { Transfer \& } \\
\text { Rotate }\end{array}$ \\
\hline Type & & & $\begin{array}{l}\text { Screw Driven, } \\
\text { Vertical } \\
\text { Grapple \& } \\
\text { Rotating Hor- } \\
\text { 1zontal Trans- } \\
\text { fer Arm }\end{array}$ & & $\begin{array}{l}\text { Offset Arm, } \\
\text { Ball Screw } \\
\text { Vertical Drive, } \\
\text { Gear Rotation } \\
\text { Drive }\end{array}$ & $\begin{array}{l}\text { Offset Arm, } \\
\text { Chain Hoist } \\
\text { Vertical Drive, } \\
\text { Gear Rotation } \\
\text { Druve }\end{array}$ & $\begin{array}{l}\text { Chain \& Tele- } \\
\text { scoping Drives, } \\
\text { Vertical Grapple, } \\
\& \text { ? }\end{array}$ & $\begin{array}{l}\text { Chain \& Tele- } \\
\text { scoping Drives, } \\
\text { Vertical Grapple }\end{array}$ \\
\hline Cooling & & & Under Sodium & & Under Sodium & Under Sodium & Under Sodıum & Under Sodium \\
\hline \multicolumn{9}{|l|}{ Ex-Vessel Handling } \\
\hline Function & $\begin{array}{l}\text { Ex-Vessel } \\
\text { Transfer }\end{array}$ & $\begin{array}{l}\text { Ex-Vessel } \\
\text { \& In-Vessel } \\
\text { Transfer, } \\
\text { Rotation }\end{array}$ & $\begin{array}{l}\text { Ex-Vessel } \\
\text { Transfer }\end{array}$ & $\begin{array}{l}\text { Ex-Vesse1 } \\
\text { Transfer }\end{array}$ & $\begin{array}{l}\text { Transfer From } \\
\text { Reactor Build- } \\
\text { ing to Fuel } \\
\text { Building }\end{array}$ & $\begin{array}{l}\text { Ex Vesse1 } \\
\text { Transfer }\end{array}$ & $\begin{array}{l}\text { Ex-Vessel } \\
\text { Transfer }\end{array}$ & $\begin{array}{l}\text { Ex-Vesse1 } \\
\text { Transfer }\end{array}$ \\
\hline Type & $\begin{array}{l}\text { Steel Cable, } \\
\text { Vertical } \\
\text { Grapple }\end{array}$ & $\begin{array}{l}\text { Bridge } \\
\text { Crane, } \\
\text { Steel Cable, } \\
\text { Vertical } \\
\text { Grapple }\end{array}$ & $\begin{array}{l}\text { Link Chain, } \\
\text { Vertical } \\
\text { Grapple }\end{array}$ & $\begin{array}{l}\text { Roller Chain, } \\
\text { Vertical } \\
\text { Grapple }\end{array}$ & $\begin{array}{l}\text { Steel Tape, } \\
\text { Vertical Grapple }\end{array}$ & $\begin{array}{l}\text { Roller Chain, } \\
\text { Vertacal Grapple }\end{array}$ & $\begin{array}{l}\text { Steel Tape, } \\
\text { Cable, \&? }\end{array}$ & $\begin{array}{l}\text { Steel Tape, Cable, } \\
\text { \& Telescoping } \\
\text { Tube, Vertical \& } \\
\text { Horizontal Grapple }\end{array}$ \\
\hline Cooling & $\begin{array}{l}\text { Natural } \\
\text { Convection }\end{array}$ & $\begin{array}{l}\text { Cell } \\
\text { Atmosphere }\end{array}$ & Forced Argon & $\begin{array}{l}\text { Forced } \\
\text { Helium }\end{array}$ & Forced Argon & $\begin{array}{l}\text { Alr-Cooled } \\
\text { Sleeve }\end{array}$ & $\begin{array}{l}\text { Cooled Sleeve \& } \\
\text { Forced Gas }\end{array}$ & $\begin{array}{l}\text { Cooled Sleeve, } \\
\text { Forced Gas, \& } \\
\text { Cooled Dip Tube }\end{array}$ \\
\hline Heat Removal $[\mathrm{kW}(\mathrm{th})]$ & & & 3 & $\sim 10$ & 4 & 10 & $15-45$ & $20-50$ \\
\hline Fuel Assembly Container & None & None & None & None & Na-Fulled Pot & Na-Filled Pot & $\begin{array}{l}\text { Na-Filled Pot \& } \\
\text { Transfer Tube }\end{array}$ & $\begin{array}{l}\text { None \& Na- } \\
\text { Filled Pot }\end{array}$ \\
\hline
\end{tabular}




\section{DEVELOPMENT AND TESTING FOR FFTF COMPONENTS}

Development of reliable components for use in the FFTF assumes top priority in the present LMFBR program. A joint industrial-USAEC coordinated effort is being followed. Contracts covering development, design, and fabrication of major FFTF components were awarded to industrial suppliers, following extensive conceptual design studies.

To the maximum extent practicable, FFTF components utilize modest extrapolations of design features proven through previous plant operating experience. The FFTF $1050^{\circ} \mathrm{F}$ reactor outlet sodium temperature, coupled with a 20-year plant design life, requires an extension of today's technology for sodium system components. Consequently, special emphasis is placed upon developing high-temperature structural design criteria, including stress analysis techniques. The USAEC standards program being implemented for procurement of FFTF components is expected to provide sound bases for specifying design and fabrication procedures consistent with needs of demonstration and commercial plant equipment. Major design parameters for the FFTF components were included in Tables II to VI.

Primary sodium pumps

The pumps are centrifugal, tank-type pumps, with many features similar to the units used in the Fermi plant, except that the impeller inlet is ducted. Model testing is being performed to substantiate the analysis of the pump suction inlet geometry. Other developmental testing is being conducted to establish the design adequacy of: (1) the hydrostatic bearing, (2) the hard-facing materials used in the hydrostatic bearing, and (3) the pump shaft cover gas seal. A full-scale prototype of the FFTF primary pump will be tested in a water test facility and in the SPTF, to verify performance characteristics prior to FFTF plant operation.

Valves

FFTF sodium system valves range in size from $1 / 2$ to $28 \mathrm{in}$. in diameter; the small sizes are of conventional design. The large primary system isolation and check valves are of unconventional design, because there are none available that can meet system requirements with respect to the combination of design temperatures, thermal transients, sealing capability, and allowable pressure drop.

The test program planned, or in progress, for these valves includes scaled-down air and water loop flow tests of both types of valves. These tests will verify calculated pressure drops and flow characteristics. The isolation valve stem freeze seal concept is based on highly localized heat removal, using a comparatively short axial cooling section. Since the concept has not previously been demonstrated, a subcomponent test of the principle is being considered. Finally, full-scale prototypes will be tested in sodium, to evaluate overall performance of the entire valve.

\section{Intermediate heat exchangers}

The IHX's are vertical, shell and tube type, having removable tube bundles, similar to units used in the Fermi plant. Water testing of models is being performed, to substantiate hydraulic and vibration analysis results. Models of highly stressed structural members, typical of tube - tube sheet 
joints, are being subjected to fatigue cycle testing under prototype sodium temperature transients. A full-scale prototype of the FFTE IHX will ultimately be tested in the SCTI at reduced power conditions, to characterize performance and to demonstrate proposed maintenance techniques, prior to FFTF plant operation.

Fuel handling equipment

In general, the fuel handling and interim examination and maintenance cell equipment designs are "state of the art." However, some design features are unique in application, and have been selected for "feature testing. " Examples of the feature tests are In-Vessel Handling Machine (IVHM) guide roller tests in sodium, and sodium removal process equipment for the Interim Examination and Maintenance Facility.

The full-scale tests at the High-Temperature Sodium Facility (HTSF) will be performed to demonstrate the technical feasibility of the design concept, to verify the design, and to furnish data for design refinements. These tests will further demonstrate that all interfaces and operational and maintenance requirements have been satisfied. Prototypic and/or actual plant hardware will be tested. Tests will be performed dry, using the Core Mechanical Mockup (CMM), and in sodium, using the Composite Reactor Components Test Activity (CRCTA).

\section{TEST FACILITIES}

There is a wide variety of test facilities available in the United States. The characteristics of these facilities, and facilities under construction, are summarized in Table VII.

\section{REFERENCES}

[1] Atomics International, 1000-Mwe LMFBR Follow-on Study, USAEC Rep. AI-AEC-12791, AI-AEC-12792, and AI-AEC-12793 (1969)

[2] Babcock and Wilcox, 1000-Mwe LMFBR Follow-on Study, USAEC Rep. BAW-1328 and BAW-1331 (1969)

[3] General Electric, 1000-Mwe LMFBR Follow-on Study, USAEC Rep. GE-5678 and GE-5769 (1969)

[4] Westinghouse, 1000-Mwe LMFBR. Follow-on Study, USAEC Rep. WARD-2000-97 and WARD-2000-90 (1969) 


\section{TABLE VII}

\section{SUMMARY OF TEST FACILITY CAPABILITIES AND CHARACTERISTICS}

(Sheet 1 of 2 )

\begin{tabular}{|c|c|c|c|c|c|c|}
\hline \multirow[b]{2}{*}{ Facility } & \multirow{2}{*}{$\begin{array}{c}\text { Year } \\
\text { Con- } \\
\text { structed }\end{array}$} & \multicolumn{3}{|c|}{ Design \& Operating Conditions } & \multirow[b]{2}{*}{$\begin{array}{r}\text { Material } \\
\text { (p1ping) }\end{array}$} & \multirow[b]{2}{*}{ Comments } \\
\hline & & $\begin{array}{l}\text { Pressure } \\
\left(1 \mathrm{bt} / \mathrm{m}^{2}\right)\end{array}$ & $\begin{array}{l}\text { Temperature } \\
\text { (OF) }\end{array}$ & $\begin{array}{c}\text { E low } \\
(\mathrm{gal} / \mathrm{m} \mathrm{mn})\end{array}$ & & \\
\hline \multicolumn{7}{|l|}{ Argonne National Laboratory (ANL) } \\
\hline Core Component Test Loop (CCTL) & 1965 & 150 & 1200 & 800 & $304 S S$ & $\begin{array}{l}\text { Hydraulic flow test of fuel subassemblies } \\
\text { and mstruments }\end{array}$ \\
\hline Sodum Flow Sensor Calibration Facility & 1965 & $30 / 10$ & $900 / 800$ & 100 & $304 \mathrm{SS}$ & $\begin{array}{l}\text { Intended only for sodium flow sensor } \\
\text { calibration }\end{array}$ \\
\hline $\begin{array}{l}\text { Component and Materials Evaluation Loop } \\
\text { (CAMEL) }\end{array}$ & 1967 & $150 / 100$ & 1200 & 200 & $304 S S$ & $\begin{array}{l}\text { Isothermal testing of components and } \\
\text { materals }\end{array}$ \\
\hline Fuel Falure Detection Loop & 1965 & $30 / 30$ & $1300 / 1200$ & 30 & 304 SS & Test fission gds detector devices \\
\hline Hxperiment $d$ I Breeder Reactor II (EBR-II) & 1957 & $90 / 80$ & $900 / 880$ & $9000 / 5890$ & $\begin{array}{l}304 \text { SS \& } \\
\text { Croloy }\end{array}$ & This is an active FBR power plant \\
\hline $\begin{array}{l}\text { FBR-II Out of-Core Nuclear Instrument } \\
\text { Test Loop (NITL) }\end{array}$ & 1970 & - & $700-1200$ & - & SS & $\begin{array}{l}\text { Test experimental neutron detectors } \\
\text { and cable }\end{array}$ \\
\hline Large TRF AT Sodum Loop & 1968 & $150 / 75$ & $1025 / 932$ & 160 & $304 S S$ & $\begin{array}{l}\text { Fuel meltdown studies under flowing } \\
\text { sodium }\end{array}$ \\
\hline High Temperature Furnace Facility & - & - & 5070 & - & - & Test components at ultrahigh temperatures \\
\hline \multicolumn{7}{|l|}{$\begin{array}{l}\text { Atomic Power Development Associates, } \\
\text { Inc (APDA) }\end{array}$} \\
\hline APDA Sodnm Endurance Loop & 1959 & $120 / 130$ & $1000 / 1000$ & 350 & $304 \mathrm{SS}$ & $\begin{array}{l}\text { Test reactor subassemblies in flowing } \\
\text { sodium }\end{array}$ \\
\hline APDA Sodrum Technology Loop & 1961 & $175 / 35$ & $1200 / 1000$ & $\begin{array}{l}200 \text { mann } \\
75 \text { side }\end{array}$ & $316 \mathrm{SS}$ & $\begin{array}{l}\text { Evaluate in-line instruments and purifica- } \\
\text { tion devices }\end{array}$ \\
\hline APDA Rig 10 & 1965 & $125 / 75$ & $800 / 610$ & 400 & C sted & Investigate small water leaks into sodum \\
\hline $\begin{array}{l}\text { Enrico Ferm Atomic Powt Plant } \\
\text { (EFAPP) }\end{array}$ & 1965 & 125 & 1000 & 20,000 & 304 SS & $\begin{array}{l}\text { Full-scale industral fast reactor power } \\
\text { power plant }\end{array}$ \\
\hline \multicolumn{7}{|l|}{ Atomics International (AI) } \\
\hline High-Temperature Sodum Supply System & 1969 & $100 / 30$ & $1200 / 1200$ & $\mid \begin{array}{l}60, \text { each } \\
\text { of } 2 \text { pumps }\end{array}$ & 304SS & $\begin{array}{l}\text { Tests on control rod components at } \\
\text { reactor operating conditions }\end{array}$ \\
\hline Redctor Sodum Fnvironment Chamber & 1969 & $50 / 20$ & $1200 / 1200$ & 20 & $304 S S$ & $\begin{array}{l}\text { Simulatid reactor environment, } \\
\text { especially sodium vapor }\end{array}$ \\
\hline Low-Temperature Sodum Supply System & 1969 & $100 / 20$ & $1200 / 600$ & 20 & $304 \mathrm{SS}$ & $\begin{array}{l}\text { Tisting components at reactor refueling } \\
\text { temperatures }\end{array}$ \\
\hline LMFBR 2-1n Flowng Sodun Loop & 1967 & 21 & $1300 / 1200$ & 40 & $304 S S$ & $\begin{array}{l}\text { Effects of environmental factors on } \\
\text { mechanical properties of fuel cladding } \\
\text { materials }\end{array}$ \\
\hline \multicolumn{7}{|l|}{ Babcock \& Wilcox Co (B\&W) } \\
\hline Model Sodrum Hedted Steam Generator & 1964 & $\begin{array}{l}\mathrm{Na} 60 / 30 \\
\mathrm{H}_{2} \mathrm{O} 2400\end{array}$ & $\begin{array}{l}\mathrm{Na} 1200 / 1100 \\
\mathrm{H}_{2} \mathrm{O} 1050(\mathrm{op})\end{array}$ & $\begin{array}{l}\mathrm{Na} 25 \\
\mathrm{H}_{2} \mathrm{O} 115\end{array}$ & $316 \mathrm{SS}$ & Steam generator and corroston studies \\
\hline \multicolumn{7}{|l|}{ Brookhaven National Laboratory (BNL) } \\
\hline $\begin{array}{l}\text { Sodium Heat Transfer Facility } \\
\text { Generdl Electric Co }(\mathrm{GH})\end{array}$ & 1968 & $100 / 80$ & $\begin{array}{l}1600 / 1600 \\
1000\end{array}$ & 35 & $\begin{array}{l}316 / \\
304 \mathrm{SS}\end{array}$ & Tests of core design and safe operation \\
\hline $\begin{array}{l}\text { Loop No } 11 \text { Thermal-Hydraulic, } \\
\text { Fucl and Flow Test Loop }\end{array}$ & 1965 & $300 / 60$ & $1300 / 1000$ & 80 & SS & $\begin{array}{l}\text { Thermal and hydraulic testing of } \\
\text { LMFBR components }\end{array}$ \\
\hline Stedm Generator Test Rig & 1969 & $250 / 125$ & $1100 / 1000$ & 180 & $304 \mathrm{SS}$ & Heat transfer studıes \\
\hline $\begin{array}{l}\text { Southwest Fxperimental Fast Oxide } \\
\text { Reactor (SEFOR) }\end{array}$ & 1968 & 100 & 1050 & 5000 & 304SS & $\begin{array}{l}\text { A } 20-\mathrm{MW}(\mathrm{th}) \text { fast breeder leactor, fueled } \\
\text { with sodum and uranum oxides } \\
\text { Owned by utlities, GE, Furatom, etc }\end{array}$ \\
\hline SEFOR Refueling Cell Mockup & - & 10 & $1000 / 400$ & $20 / 10$ & - & $\begin{array}{l}\text { Temperature study, demonstrate refuel } \\
\text { ing system and tratning }\end{array}$ \\
\hline
\end{tabular}


TABLE VII

SUMMARY OF TEST FACILITY CAPABILITIES AND CHARACTERISTICS (Sheet 2 of 2)

\begin{tabular}{|c|c|c|c|c|c|c|}
\hline \multirow[b]{2}{*}{ Facality } & \multirow{2}{*}{\begin{tabular}{|c|}
$\begin{array}{c}\text { Year } \\
\text { Con- } \\
\text { structed }\end{array}$ \\
\end{tabular}} & \multicolumn{3}{|c|}{ Design \& Operatıng Conditions } & \multirow[b]{2}{*}{$\begin{array}{l}\text { Material } \\
\text { (piping) }\end{array}$} & \multirow[b]{2}{*}{ Comments } \\
\hline & & \begin{tabular}{|l|} 
Pressure \\
$\left(\mathrm{lbf} / \mathrm{m}^{2}\right)$ \\
\end{tabular} & $\begin{array}{c}\begin{array}{c}\text { Temperature } \\
\left({ }^{\circ} \mathrm{F}\right)\end{array} \\
\end{array}$ & $\begin{array}{c}\text { Flow } \\
(\mathrm{gal} / \mathrm{m} 1 \mathrm{n})\end{array}$ & & \\
\hline \multicolumn{7}{|l|}{$\begin{array}{l}\text { Hanford Engineering Development } \\
\text { Laboratory (HEDL) }\end{array}$} \\
\hline $\begin{array}{l}\text { Core Segment Development Faculty } \\
\text { (CSDF)(a) }\end{array}$ & $1971^{(b)}$ & 50 & 1200 & Static & $304 \mathrm{SS}$ & $\begin{array}{l}\text { Vessel } 2-1 / 2 \mathrm{ft} \text { diameter } \times 42 \mathrm{ft} \text { long } \\
\text { Operational environment for testing } \\
\text { full-length LMFBR components }\end{array}$ \\
\hline $\begin{array}{l}\text { Fast Reactor Thermal Engineering } \\
\text { Facility (FRTEF)(a) }\end{array}$ & $1971(\mathrm{~b})$ & 300 & 1200 & $\begin{array}{l}600 \mathrm{dt} \\
200 \\
1 \mathrm{bf} / \mathrm{m}^{2}\end{array}$ & $304 \mathrm{SS}$ & $\begin{array}{l}\text { For design and safety testing of heated } \\
\text { FFTF fuel subassemblies Loop test } \\
\text { section to } 1800^{\circ} \mathrm{F}, 39-\mathrm{pin} \text { assembly can } \\
\text { be tested at } 10^{6} \mathrm{Btu} / \mathrm{hr}-\mathrm{ft}^{2} \text { heat flux }\end{array}$ \\
\hline $\begin{array}{l}\text { High-Temperature Sodium Faclity } \\
\text { (HTSF)(a) }\end{array}$ & $1971(\mathrm{~b})$ & - & - & - & - & $\begin{array}{l}\text { High-bay sodium facilty, } 45,000 \mathrm{gal} \\
\text { sodium storage Will house CRCTA and } \\
\text { future faclities }\end{array}$ \\
\hline $\begin{array}{l}\text { Composite Reactor Component Test } \\
\text { Activity (CRCTA)(a) }\end{array}$ & $1972(\mathrm{~b})$ & 50 & 1100 & Static & $304 \mathrm{SS}$ & $\begin{array}{l}\text { "Quas1-static" sodium system for full- } \\
\text { scale testing of FFTF in-vessel \& ex- } \\
\text { vessel equpment, including IVHM, } \\
\text { Instrument Tree Core Restraint, Closed } \\
\text { Loop Ex-Vessel Mdchine, \& Floor Valve } \\
\text { Test Vessel } 15 \text { ft iD x } 36 \mathrm{ft} 4 \text { in length }\end{array}$ \\
\hline \multicolumn{7}{|l|}{ Lıquid Metal Engıneerıng Center (LMEC) } \\
\hline $\begin{array}{l}\text { Sodium Components Test Installation } \\
\text { (SCTI) }\end{array}$ & 1964 & $125 / 90$ & $1300 / 1200$ & 3000 & 304 SS & $\begin{array}{l}\text { Tests of heat exchangers and steam } \\
\text { generators }\end{array}$ \\
\hline Large Components Test Loop (LCTL) & 1958 & 25 & 1000 & 2000 & $\begin{array}{l}2 \mathrm{l} / 4 \mathrm{Cr} \\
1 \mathrm{Mo}\end{array}$ & $\begin{array}{l}\text { To be succeeded by the Small Com- } \\
\text { ponents Test Loop (SCTL) }\end{array}$ \\
\hline Pump Seal Test Facllity (PSTF) & 1969 & $55 / 50$ & $1400 / 1200$ & 0 to 55 & $304 S S$ & $\begin{array}{l}\text { Tests of pump seals and mechanisms } \\
\text { not necessarily related to pump, such } \\
\text { as control rod drives }\end{array}$ \\
\hline $\begin{array}{l}\text { Sodium Mechanisms Test Installation } \\
\text { (SMTI) }\end{array}$ & 1966 & 25 & 1200 & - & $304 S S$ & $\begin{array}{l}\text { Tests of materials and mechanisms in } \\
\text { sodium liquid and/or vapo1 }\end{array}$ \\
\hline PMIS Loop II & 1970 & 15 & 1200 & 20 & $304 \mathrm{SS}$ & $\begin{array}{l}\text { Static sodium environment for mecha } \\
\text { nism testing Four test vessels }\end{array}$ \\
\hline Sodum Pump Test Fachlyty SPTF)(a) & 1972 (b) & 250 & 1200 & $\begin{array}{l}18000 \\
(\text { (nit } 1 \mathrm{~d} 1)\end{array}$ & $304 S S$ & $\begin{array}{l}\text { Flow and thermal shock capability for } \\
\text { pump, valve, and nnstrument testing } \\
\text { and calibration }\end{array}$ \\
\hline Small Components Test Loop (SCTL)(a) & 1972 (b) & 225 & 1200 & $\mid \begin{array}{l}3500 \text { at } \\
220 \\
\mathrm{lbf} / \mathrm{n}^{2}\end{array}$ & $304 \mathrm{SS}$ & $\begin{array}{l}\text { 10-in loop, cnvironmental \& transient } \\
\text { testing of piping, valves, instruments, } \\
\text { small components, \& subsystem inserts }\end{array}$ \\
\hline Pump Bearng Test Facility (PBTF)(a) & $1972(\mathrm{~b})$ & $\begin{array}{l}210 \\
\text { (bearng) } \\
300 \text { (piping) }\end{array}$ & 1050 & 600 & $304 \mathrm{H} \mathrm{SS}$ & $\begin{array}{l}\text { Proof \& performance tests of sodıum- } \\
\text { lubricated main-shaft radial bearings }\end{array}$ \\
\hline \multicolumn{7}{|l|}{$\begin{array}{l}\text { Mine Safety Applance Research Center } \\
\text { (MSAR) }\end{array}$} \\
\hline MSAR Loop-1 (High-Carbon System) & 1961 & $50 / 30$ & $1400 / 1200$ & 25 & $316 \mathrm{SS}$ & Test mechanical properties, calıbrate \\
\hline MSAR Loop-2 (High-Oxygen System) & 1961 & $50 / 30$ & $1400 / 1200$ & 25 & $316 \mathrm{SS}$ & $\begin{array}{l}\text { carbon meters Conduct stress-free } \\
\text { excursions in } \mathrm{C} \text { - or } \mathrm{O}_{2} \text {-contaminated } \\
\text { systems }\end{array}$ \\
\hline $\begin{array}{l}\text { MSAR Loop } 3 \text { (Clean Sodium, } \\
\text { Mechanical Properties) }\end{array}$ & 1968 & $100 / 55$ & $1400 / 1200$ & 85 & $316 \mathrm{SS}$ & $\begin{array}{l}\text { Mechanical properties tests with clean } \\
\text { sodium and high-velocity conditions }\end{array}$ \\
\hline MSAR 4-in Pump Test Loop & 1965 & $250 / 200$ & $1600 / 1500$ & 800 & $316 \mathrm{SS}$ & $\begin{array}{l}\text { Test expermental linear induction } \\
\text { pump }\end{array}$ \\
\hline \multicolumn{7}{|l|}{ Oak Rudge National Laboratory (ORNL) } \\
\hline LMFBR - Falled Fuel Mockup & 1970 & $100 / 90$ & $\begin{array}{l}1300 / 600 \\
\text { to } 1200\end{array}$ & 260 & $304 \mathrm{H} \mathrm{SS}$ & Investigate LMFBR fuel pin fallures \\
\hline LMFBR - Heater Test & 1969 & $30 / 25$ & $1200 / 1200$ & 5 & $316 \mathrm{SS}$ & $\begin{array}{l}\text { Determines performance of electric } \\
\text { heaters used in Falled Fuel Mockup }\end{array}$ \\
\hline \multicolumn{7}{|l|}{ Westinghouse Electric Corp } \\
\hline General Purpose Loop-1 (GPL-1) & 1967 & $330 / 230$ & $1200 / 1200$ & 200 & 304 SS & $\begin{array}{l}\text { Heat transfer, hydraulics, soduum } \\
\text { technology, and component tests }\end{array}$ \\
\hline General Purpose Loop-2 (GPL 2) & 1968 & $300 / 219$ & $1200 / 1200$ & 2000 & $304 \mathrm{SS}$ & $\begin{array}{l}\text { Test full-size fuel assemblres, control } \\
\text { lods, and large components }\end{array}$ \\
\hline
\end{tabular}

(a) Under construction

(b) Year operational 